\title{
Didactic methodology in professional e-sport training. An international experience in Brawl Stars \\ Metodología didáctica en entrenamiento profesional de e-sport. Una experiencia internacional en Brawl Stars \\ Millán Brea Castro \\ Universidad deVigo (España)
}

\begin{abstract}
The impact of eSports today is undeniable. Millions of connected players, international competitions with succulent economic awards, diversity of plafforms to participate or track the competitions. A new system of youth socializaion, channelled through video games, in which the competition requires a complete sport training This article describes the methodological strategies for teaching and learning eSportsfrom asemi-professional team. The analysed categoriesare: training typeand schedule, used tools and typology of feedback carried out for the automation of playing behaviours. The research is carried out using a qualitative approach. The datacollection is done through semi-structured interviewswith the members of the semi-professional Q LASH eSportsteam. The data were coded to simplify the interpretation and the subsequent description. In conclusion, we can point out that thetraining methodology in eSportshassimilarities with classic sport, but it does not have a structured and does not follow specific guidelines when executed by the coaches There are three types of training which usually last approximately one hour and half per day. We cannot confirm that the didactic strategies used during training will improve results during the competition.
\end{abstract}

Keywords. Education Sciences, Sport, Video Game, Methodology, Social Participation.

Resumen. El impacto de los eSports hoy en día es innegable. Millones de jugadores conectados, competiciones internacionales con suculentospremioseconómicos, diversidad de plataformasparaparticipar o seguir lascompeticiones. Un nuevo sistemade socialización juvenil, canalizado através delosvideojuegos, en el quela competición requiereun entrenamiento deportivo completo. En esteartículo se describen las estrategias metodológicas parala enseñanzay el aprendizajede los deporteselectrónicos deun equipo semiprofesional. Lascategoríasanalizadasson: tipo y calendario deentrenamiento, herramientasutilizadasy tipologíadelaretroadimentación realizadapara laautomatización deloscomportamientos dejuego. Lainvestigación sellevaacabo utilizando un enfoque cual itativo. Larecopilación de datosse realizamediante entrevistas semiestructuradas con losmiembros del equipo semiprofesional de eSportsde Q LASH. Los datos fueron codificados parasimplificar la interpretación y la posterior descripción. En conclusión, podemos señalar que lametodologíade entrenamiento en eSportstienesimilitudes con el deporteclásico, pero no tieneunaestructuray no siguedirectrices específicas cuando es ejecutada por los entrenadores. $\mathrm{H}$ ay trestipos de entrenamiento que suelen durar aproximadamente una hora y media por día. No podemos confirmar que las estrategias didácticas utilizadas durante el entrenamiento mejoren los resultados durante la competición. Palabras clave. Ciencias de la Educación, Deporte,Videojuegos, M etodología, Participación Social.

\section{Introduction}

The arrival of video games during the $1980 \mathrm{~s}$, especially due to the use of arcade machines, created a community and a social network (Castro, 2016); around these pastimes, this community has multiplied over the last 30 years. Facing the option of playing at home or sharing moments that you could be a player or a spectator, video game creators explore the possibility of combining both aspects. Portable consoles, multiplayer consoles, wireless-control consoles, ... They were pioneers of a technology that, with the emergence of the Internet, broke with the existing culture to completely change the idea of virtual entertainment

Fecha recepción: 16-09-20. Fecha de aceptación: 14-12-20

Millán Brea Castro

millan@ uvigo.es
(W hite, 2013) that we had. Currently, and with this inclusion of internet in all consoles, computers and mobile phones, the gamer community $(0$ 'Connor, Longman, W hite $\&$ O bst, 2015) no longer share recreation rooms, but did not stop playing or socializing (from home) thanks to platforms like Twitch or Youtube they can follow games and either improve or copy tricks that later will apply in the game time. Video channels like League of Legend currently have more than 20 million subscribers, and their live games can reach 100,000 viewers (Twitch Trackers, 2020).

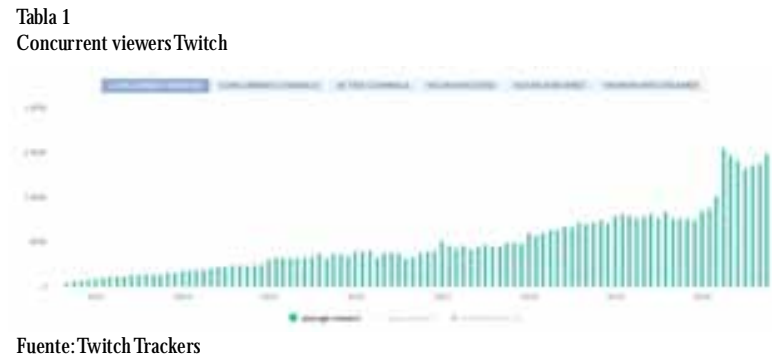


We should be aware that it is a very complex and wide field that, nowadays, is still starting to be researched. However, it impacts directly on the society, be it with a leisure resource (Varela Crespo, Varela Garrote, \& FraguelaVale, 2020), an educational resource (J uvera Portilla, Zamarripa, Ceballos Gurrola, \&Vergara Torres, 2020) or, a new sport profession (Hallmann \& Giel, 2018) for the youth.

In fact, the emergence of a new profession in the field of sport generates certain concerns in aspects such as competition, the training of coaches (Buceta, 2004), the didactic methodological process (Brea, 2015) of training or the motivation of players. These are interesting factors that we know about in other sports but that we do not know about in the field of esports.

In spite of the doubts from the more conservative sectors, it has been shown (Hamari \&Sjöblom, 2017) that their practice involves competitions similar to traditional sports. Effort, training, physical and mental wear, demanding competitions. . . This universe is comparable to any other sport practice, clearly differentiating that their skills are expressed through a physical channel such as video games. Therefore, it would be obvious that you need some training guidelines to improve your results.

In esports, with a few al ready-consolidated sport federations and with the highest number of licenses in Spain, football and basketball (M inisterio de Cultura y Deporte, 2020), the basic training is structured different levels. Reaching the superior or level 3 would give to the players accreditation to be able to train in the maximum professional category of these sports. Although this training also appears in the regulated training (Royal Decree 320/2000, of 3 M arch and Royal Decree 1363/ 2017, of 240 ctober) when trying to bring together in formal education the instruction of future coaches, a very large number of people were trained through these internal courses of the Federations during the last few years. Besides in all of these, the contents in the common blocks as well as the specific ones, favoured the acquisition of methodology of general and specific teaching

W ithout valuing the previous training, we have to emphasize that both qualified football and basketball coaches have a concrete training about didactic methodology; Also, compared to the electronic sport, these know and use strategies in order to improve in the performance of their players and teams.

However, these coaches are far from each other depending on several factors: the sport itself, the competition, the context and its facilities, the needs or goals and the players. Although the common blocks encompass pedagogical basis for teaching and general training, each team will be as a small planet around a large universe.

In Spain, entities directly related to sport training, we detect two outstanding experiences that bet towards this horizon in our country:

- The so-called «Academies», of a private nature oriented towards the training of professional players, but whose training of their teachers and the teaching method itself are unknown. Although their proposals are adapted to a very specific youth audience using very simple and dynamic stream platforms, it cannot be confirmed a direct relationship between their methodology and the results of the trained players. The rise and arrival of professional teams undoubtedly raises this type of initiative. However, according to data from the Spanish Video Game Association the number of professional players was around 250 in 2020 (only including players with a work contract). At the moment, we can simply understand these A cademias as private initiatives not oriented to the training of coaches but of players.

- U niversities that invest in the training and creation of professional teams are the ones from the Catholic University San Antonio de Murcia (UCAM) and the University of M alaga. This first one has got a gaming house and several professional teams on various platforms that compete under the University's name. Its position is oriented towards competition and the academic training of its players, instead of towards the training of future coaches.

The U niversity of M alaga has aspecific Chair, seeking to research the impact of eSports in society thanks to agreements with major clubs likeVodafone Giants. This club is located in a gaming house based in Alhaurín de la Torre. There the club develops a physical and mental training program for its players in this residential and sport area.

Finally, in regards to Spain, there is a lack of federations or projects that rule sports training in esports. On N ovember 10, 2016, the collaboration agreement between the Instituto de laj uventud (Injuve) and the National Association for the Promotion of Digital Entertainment (ANFED) was presented at the Secretariat of State for Social Services and Equal ity. The constitution of the Spanish Federation of Video Games and eSports (FEVeS) was presented there. Currently, this Federation is not active and the signed agreement 
is not available through any official government website. There is a certain opacity regarding this document that only generates many doubts about the useful ness of this agreement. We can also understand that there is some confusion when comparing video games with eSport, when relating them only to youth or when creating a federation without regulated and official competition, which could lead to conflicts between several interests.

Today, we highlight the work from the Spanish Video Game Association, with publications referring to the economic and social impact of video games, and which brings together several platforms, entities and brands under the same umbrella. W ithout a doubt, in Spain, this is the official entity with the most activity and projection in terms of video games (but not electronic sports).

Therefore, just as we distinguish traditional sports and their specific conditions, the same istrue for esports. There are several game devices (Table 2), a large number of competitions and countless different video games.

\begin{tabular}{lc}
$\begin{array}{l}\text { Table 2 } \\
\text { Favourite devices for playing esports }\end{array}$ \\
\hline Sobremesa & $63,7 \%$ \\
Portátil & $26,4 \%$ \\
Xbox one & $5,1 \%$ \\
Ps4 & $36,1 \%$ \\
Switch & $6,6 \%$ \\
Smartphone & $24,9 \%$ \\
Tablet & $6,7 \%$ \\
\hline Source: https: / es.statista.com &
\end{tabular}

We establish a small classification based on the internal dynamics of the game itself, since the final objective in professional competitions is always to beat another team (person or computer). The most outstanding at present, according to the hours of viewing (Statista, 2020):

- Sports simulation, such as NBA2K, FIFA or F1.

- First person shooter or battle royal, such as Call of Duty, CS:GO or Fornite

- Fighting games, such as Street Figther or Dragonball Figther $Z$ Star

- Real-time strategy games like Clash Royal or Brawl

- M assive online battlearena, such asD 0TA 2, League of Legends ( $L O L)$ or O verwatch

This is only a small current sample of games that have their own competitions, all of them through the Internet. Competitions ruled by their own schedules and independent rhythms. They are managed by private platformsand sponsorsthat move millions of supporters. Nowadays it would be very complex to make a list of every single video game with international competition, since their flexibility and the continuous change of their platforms is uncontrollable due to the constant appearance of new devices and alternatives. Even for the industry itself.

Therefore we delimit our field of research, choosing the mobile phone as a platform and a game that even it has not been on the market for more than three years, it already has international and world competitions, to be played in the first country in the world that provided the range of Olympic athletes to its international electronic sports players: South Korea.

Based on this background, the present article aims to describe the methodological strategies of the eSports teaching-learning process by a semi-professional team. Taking into account the type and schedule of training the didactic tools used and the typology of feedback carried out for the automation of playing behaviours.

Therefore, we will know key didactic factors that contribute to establish a new relationship between eSports and Pedagogy.

\section{Material \& M ethod}

The following research is based on a qualitative methodology and aims it to a subjective understanding of the dynamics and training of an esports team. It is the players and coaching staff themselves who will give meaning to the object of study with their opinions.

Therefore it will be a phenomenological and hermeneutic study (Fuster, 2019), with a methodology based on interviews to analyse, structure and define the didactic methodology in the Q LASH team training.

To delimit the field of study, we choose the mobile platform game: Brawl Stars, was officially released in June 2017. It belongs to the Real-Time Strategy genre, which combines elements from card games, tower defence and online multiplayer battles. The current platform they compete with is mobile formt, through their Android or IOS operating systems. Although with figures not comparable to games from other platforms (mainly computer), it had in Twitch in N ovember 1.508.872 followers (Twitch, 2020), indicating the high number of supporters it has. In addition, the fact that it is a mobile game, facilitates the number of players increasing daily. The quantity of downloads in the same month exceeded 14 million (Google Play Store, 2020).

Mainly, Brawl Stars is a battle with «friends» or at individual level, with a variety of game modes in less than three minutes. The modes are: Gem Grab (3 vs 3), Showdown (Solo / Duo), Bounty (3 vs 3), Heist (3 
vs 3), Brawl Ball (3 vs 3) and special events.

There are several competitions that we can find throughout the season, both professional and amateur: Brawl League, Lader EU, GG Series, etc. Focusing the research in Spain, we can emphasize the ESL Masters (ESL M aster España, 2020), one of the main competitions that classifies the teams on a European level and, later, world-wide. It is a competition of 8. Spanish clubs with a regular league phase of only one way and with a face to-face phase. In this one, the four best teams of the regular phase, will compete among themselves for the title: Boss Gaming, Arctic Gaming, Team Q ueso and QLASH.

This is therefore one of the games with the greatest social impact on mobile phones nowadays, despite its short history. O ne more reason to research and understand what processes professional teams use to work out and improve performance.

\section{Participants}

The chosen team for this research is Q LASH Team Pro, 2019 champion of the ESL M asters Spain Brawl Star. M ade out of three players, a coach and a manager, all men, ranging from 17 to 25 years old. All of them, with a more than three years experience in esports.

\begin{tabular}{|c|c|c|c|c|c|}
\hline № & Position & Sex & Age & Experience & Weekly hours \\
\hline 1 & Gamer1 & Male & 18 & $3+$ & 8 \\
\hline 2 & Gamer2 & Male & 18 & $3+$ & 8 \\
\hline 3 & Gamer3 & Male & 19 & $3+$ & 8 \\
\hline 4 & Coach & Male & 26 & $5+$ & 10 \\
\hline 6 & Manager & Male & 26 & $5+$ & 20 \\
\hline
\end{tabular}

\section{Instruments}

Due to several limitations, such as the inability of holding face-to-face meetings between players and coaching staff, or the difficulty of establishing semistructured interviews due to the lack of flexible timetables for players, a structured interview sent by the researcher to each of the participants was chosen. In this way, we facilitated on the one hand reflection on the response without time constraints, and on the other hand the freedom to freely express themselves without fear that the rest of their colleagues might challenge their opinions (Bohórquez \& Checa, 2017).

\section{Procedure}

In order to research the internal dynamics of the Brawl Stars SpainTeam Pro, we initially contacted their manager. This was the person in charge of explaining us how the club works, and getting us in touch with players and coaches. Even so, weencountered several difficulties in the process. Firstly, that research about teaching methodology in electronic sports is barely developed, although there are several relevant experiences () uvera Portilla, Zamarripa, Ceballos Gurrola, \& VergaraTorres, 2020; SantamaríaG uzmán, Solano M ora, M oncada Jiménez, \& Salicetti Fonseca, 2018).

However, research to determine the methodological processes used for learning this type of game is still in its childhood.

Once we obtained the approval of the club, in this case its representation (manager), we proceeded to send the surveys to each one of the player sand coaches. During the response process, we enabled an online chat on the same platform in order to resolve any doubts or interpretations that the questions can raise. The clarifications would only be given at the request of the player, to not condition the answers.

A total of five virtual interviews were conducted with the whole team that plays the official Q lash competitions in the Brawl Stars video game.

\section{Results}

The results have been organised into categories to ease their interpretation and understanding: Type and schedule of workout, used tools and typology of the feedback carried out for the automation of playing behaviours.

\section{Type and schedule of workout}

The training sessionsare in a daily bases, from M onday to Friday, an hour and a half each day. The schedules are specific, previously specified with the sports group according to their daily tasks, with a monthly calendar. Logically, this calendar is flexible in terms of competitions, which may vary due to calls or tournaments initially not scheduled.

The organization seems clear, although many times it will be conditioned to personal circumstances, causing not having professional players working exclusively for the team. There are three types of workout sessions in the team: Scrim, Ladder and Internal, which are organized in a common way, based on a previous planning made by the coach: rating availability of players, dates and competitions in which they are going to participate.

As for Scrim, it would be an unofficial meeting against another team to set up the initial game of a competition. It is a warm-up ( $M$ éndez-Giménez, Fernández-Río \& Méndez-Alonso, 2015) as there is no 
initial guideline except to play the game.

Ladder: All the players of the team, will play simultaneously and together several games in a continuous way and during at least 1 hour time. $0 n$ this occasion, they will be constantly communicating, and will correct the moves at the same time as they are immersed in the game.

Internal: In this case, the workout is done between the 3 player sand the coaches, to work on specific moves in a 3 vs 3 format. Precisely, this session is key, since the moves are «monitorised» previously.

\section{U sed tools}

Each session, whatever is the chosen training model is carried out in a face-to-face way and is done through a platform called «Discord» (2020). This application, a voice and text chat, is connected while playing, and from there the instructions are given, which are usually through voice, since they could not be pending a lesson. The coach role is to point out and give instant feedback of the player's mistakes and, that character compositions (combos) can be adjusted to improve the score.

\section{Typology of the feedback carried out for the automation of playing behaviours}

Due to this type of game's reality, the team does meet up neither during the previous competition nor during the training sessions, only during the final game that gives the qualification for the World Cup, so it is complicated to research at individual level accompanying each player, as they are in very different geographical points. Despite this, they work with enabled platforms to facilitate communication, always on streaming

The coach is not in a face-to-face way, and he must manage through communication via «streaming» (Jackson, 2011) their workoutscan becomean important challenge, as we will see in the conclusions.

All players under 20 years old balance their studies with the game. Therefore, we understand that, although the team competes on an international level and travels to tournaments all around the world, as to Paris, Poland or South Korea, they do not live exclusively from electronic sports and their income is minimal. They could bbarely be considered in the category of amateur or semi-professional players (García-Lanzo \& Chamarro, 2018)

The coach usually shares this same situation, but with more working hours and other responsibilities such as analysis of rivals, preparation strategies or group management.
The manager is responsible for managing correctly (Parejo \& Sánchez, 2007) the group and make sure that each member assumes his specific role. He attends regularly, but without a specific schedule to the training sessions only as a spectator.

He has weekly meetings with the coaches and conversations with players about their performance, without making corrections to the game or interfering on strategic decisions of the game.

Corrections will depend on the type of training. In Scrim, no strategy is amended. In Ladder, the coach, corrects in the exact moment they consider a bad choice or execution is taking place, modifying decisions according to failures they detect. Therefore, when facing a a previous situation that was not properly managed in attack or defence, they providea later alternative. Finally, in the internal workouts, there are specific previous guidelines that they have to carry out, without any reflection.

The period between games is also used to analyse what happened in the last game. This analysis does not seek aweighting and a proposal from the player. It simply makes a amendment if necessary. There is no feedback and the players in this case do not get an analysis process that allows them to choose the best option among those specific failures.

As for the scouting of the opponent, this is done after the match, and usually with enough timeto practice strategies to counteract their potential. A previous vision is made and it is highlighted by the coach: the style of play, their strengths and the dynamics of their last games. $W$ ith this information, a concrete tactic is traced.

\section{Discussion}

esports, despite going unnoticed by adults, are today probably one of the biggest leisure references for the world's youth. This implies that its social, economic and cultural impact will condition future generations on a direct way.

But also, its growth derives in more and more impressive competitions and in anew profession: eSports players.

For this reason, the importance of knowing the game platforms, the types of games and the structures of the teams becomes essential to understand the reality of this business. Also, to propose from the pedagogy of sport, training and methodology in the learning processes of the players, in any of the games in which they participate. 
The organization seems clear, although many times it will be conditioned to personal circumstances, due to not have professional players working exclusively for the team.

Taking advantage precisely of this internal organization, we emphasize that the possibility of being able to see the previous games, comment on them and look for solutions between coach and player, but being the latter the one who formulates which ones, would be essential for him to facilitate us a quick decision making without the need of external support. It would promote autonomy in the game, and more so taking into account that during official games the figure of the coach is silent. It is essential to make the players an active part of the learning process.

Therefore, it is understood that the internal training dynamics of a Brawl Stars team is not very different from a traditional team in any other sport. The key to understand the function and explain the methodology used by the coaches is overall to change the traditional perspective we have about training with the physical presence of the players. The teaching methodology in electronic sports is based on several network resources and video and audio platforms, without the presence of the group in the same physical space.

And here we have one of the first key factors: the need of training in the correct use of technologies. And we are not referring to a handling of the application, but to a use that favours the players to assume what we want to explain. We have countless possibilities, but we are underestimating the pedagogical key in this whole process.

There is no doubt that the results are optimal. Because they are objective and are measured in the final results and in the victories of the championships. This indicates that it is related to the initial level of the players, who were signed up when their performance was al ready above average. It would be interesting to be able to analyze the effectiveness of training in players who have just started and are undergoing training with guided guidelines. In this way, we could analyze if there is an improvement in the final results. At present, teams like Q LASH, sign players through their scores, so they arrive at the competition al ready with developed skills.

There are schedules, there are guidelines and rules previously established of how the session will be, but not a reflection on the didactic methodology applied. The coach, depending on the results and the previous games, gives positive or negative reinforcements: «mistakes are usually corrected after the games, whether you win or lose, unless they are very serious mistakes, in order to immediately avoid them « (coach, personal communication, 220 ctober 2019). No thought is given to how to explain these corrections or how they should be made to improve performance. Therefore, a possible future research could focus on the didactic figure of the esports coaches, to work on the key aspects, to lead to the reflection of the coaches and, to favour the acquisition of tools that lead to a better understanding of the concepts and orders.

It is also not clear that there is a feedback between the instructions and the final results. Negative reinforcements tend to prevail over positive ones, giving more importance to defeat than to victory: «if we win we start talking about what's coming next, to start preparing ourselves. If we lose, we usually analyse mistakes in order to improve» (player 1 , personal communication, 22nd 0 ctober 2019).

Players even regret that the used strategies do not have direct results, and would change without hesitation as they believe that sometimes they do not understand where the mistakes are in their game when they win: «there is no such thing as a perfect game and even more so when you play at such a high level» (player 2, personal communication, 220 ctober 2019). Curiously, they do not propose formulas or strategies either, although we interpret that they ask for greater freedom of decision at certain times, in order to be able to make mistakes or improve their progression, and the possibility of having training sessions more regularly: «it could be improved in many ways if it were very constant with very fixed schedules and more» (Player 3, personal communication, 0 ctober 22, 2019).

We observe that only in the internal workouts, where if the tactics are directed to improve the performance, a positive result can be obtained; since there are no external factors and the environment is much more relaxed: «We do the trainings using the Discord platform where we can communicate by voice with the players, then we comment them their mistakes throughout the games, we decide which combos (character compositions) can be good in each map and we prepare ourselves to win the matches». (manager, personal communication, 0 ctober 22, 2019). There is also no room for criticism or improvisation, thuslimiting the freedom of expression of each player.

The coach could work on his methodological resources (Díaz Barahona, Monfort Pañego, \& Molina García, 2020), as we show that the players are not able to assume the explanations with total clarity. Resources 
exist and are largely accessible to everyone, who can use them for both individual and collective improvement, but they will be useless if we do not give importance to the knowledge transmission. It would be an interesting proposal to adapt them to the context and to find methods that encourage real feedback. M ake everyone feel accompanied in the learning process. Positive reinforcements in each action will improve this sporting growth. Furthermore, it is essential to influence a proactive learning process that will promote real participation and motivation. This way, we will improve the ability for teamwork, virtual communication and decision making and conflict resolution at group level.

On an individual level, we would achieve greater creativity in decision-making, a better ability for analysis and, without doubt, self-efficient and cooperative learning would be consolidated (Canizales, Ries, \& Rodríguez, C., 2020)

This individual growth can also lead to greater flexibility when changing platforms and even games.

Positive reinforcements (Díaz \& Mandado, 2004), as well as self-reflection and spaces for expression will undoubtedly enhance performance and possibly ease of decision making at key starting points.

Finally, «distance» training can be an opportunity to improve virtual communication, for which coaches must also set up guidelines and recognise silences, verbal expressions and locate needs. Players warn that it is a very likely resource for improvement: «by viewing the matches from outside the games it is easier to see the errors in each move, attack or defence» (Player 2, personal communication, 0 ctober 22, 2019). Therefore, instead of focusing on the limitations, take advantage of the infinity of resources, not staying in just one application, but it is necessary to immerse ourselves in the network and know the possibilities that we always have, according to the characteristics of the group. The existence of gambling houses (sport centres for players), combines this practice, having physically all the equipment, but playing individually each one in their own device. It ispossible that the structured coexistence could speed up the improvement processes and the team work, although it does not have to be exclusive of a face-to-face coexistence. Joint leisure and free time activities, sports, watching films and reading clubs will influence the good enviroment of the group, although at the time of performance there are no current researches today that can confirm this relationship in the playhouses. Their manager is aware of this and advocates this strategy for future workout sessions: «Training all together in the classroom, this could be done in a gaming house set up by the club for example» (M anager, personal communication, 0 ctober 22, 2019).

In the light of the analysis and interviews, we can conclude that there is a didactic methodology in the Q LASH trainings in the Brawl Stars game, but that it does not go beyond aclassical presentation of suggestions and instructions, and that the coaches keep the traditional guidelines during their training.

The fact that the game is fully measurable allows us to know which players are currently the best, but not potentially which of them, with different training, could become great competitors. It is a totally objective and quantifiable competition for scores, but it does not guarantee the emergence of new players until new training mechanics are developed.

\section{Conclusions}

The research carried out showcases the structure of a semi-professional eSport team.

Itsstructure divided in types and schedules of training, used tools and the feedback methodology for the automation of behaviours was exposed trying to adapt to the reality of these new competitions.

It is very interesting to start defining and analysing the dynamics of the new teams and in this way, try to provide from the Sport Pedagogy, tools that improve the players performance.

This research, although it is focused on a single piece of equipment and a platform, opensthe door to numerous researches within esports.

It is possible that the economic impact generated by the video games in Europe in late years will lead governments to create solid eSports federations and to establish training levels for their coaches. As well as the possibility that eSports will at some point become an Olympic sport.

Finally, the use and analysis of alarge volume of data through Big Data, will be a key to the future training in the didactics applied to sports training. Currently, this data system is al ready used by for example professional teams in the NBA.

We assume that a specific training proposal for coaches cannot start from scratch. It must be based initially on the knowledge of the teaching methodology applied to the sport practice. Even in comparison with other sports and their specific training (López M uñiz, Jaenes Sánchez,Vázquez Cano \& López M eneses, 2019). 
O nce we have laid these foundations, we will move on to create specific training which will not be easy, as we explained earlier that there is a great variety of platforms and judges, so this specificity must be conditioned by these factors.

It is possible to create a degree that accredits the training of sports coaches, but there are many prior questions that must be sorted out: The institution or organization that must carry it out. The duration and the curriculum. The students profile and the conditions for their access. The accreditation that allows only qualified or unqualified people to be trained.

It is a process that we must open and that must generate a very interesting debate between education professionals and sports professionals.

By contrast, the access to video games is associated with young people, who take up this practice as aleisure activity, until they reach high levels of competitiveness, only then they will set themselves professional goals. This vision generates an interesting debate, regarding the moment in which to bet on a specific training or not, until they are recruited by a club. Leaving the decision to become professional in the hands of so called professional clubs. Therefore, what consequences can this have? As for families, how can they get to understand the universe and competitions to which their children will be exposed?

There is also a very interesting gender division. The competition itself does not rule out or divide by sex, but it is obvious that women are not attracted to online competition (Statista, 2019). The option of setting initiatives by clubs and even by the video games themselves would be the basis for fostering gender equality (Rodríguez \& M iraflores Gómez, 2018).

Finally, the year 2020 became the year when there was the greatest online consumption of video games, probably due to the crisis generated by the COVID-19. During which the impossibility of leaving home led to the search for other leisure systems for young people (Statista, 2020).

But it is also the year of the arrival of the new generation of consoles. An improvement in gameplay, graphics and connectivity to global slave.

A universe that does not stop growing, and that opens very attractive research paths in sports and education sciences.

\section{References}

AEVI (2019). Recuperado 18 de noviembre de 2020, de http:/ / www. aevi.org.es/ e-sports/ .

Bohórquez Gómez-Millán, M. R., \& Checa Esquiva, I. (2020). Medidas psicométricas de la cohesión en equipos de trabajo universitarios. Retos: nuevas tendencias en educación física, deporte y recreación, (37), 108-114.

Blanco, A. V. (2013). Las redes sociales virtuales como espacios de ocio digital. Fonseca, Journal of Communication, (6), 155-182.

Buceta, J. M. (2004). Estrategias psicológicas para entrenadores dedeportistasjóvenes. LibreríaEditorial Dykinson.

Brea Castro, M. (2015). Dos más uno: Manual didáctico para monitores/as de baloncesto. O urense: Asociación Universitariade Ciencias daEducación: Estou, Escola deTempo libre U niversitario do Campus de 0 urense.

Canizales, W. , Ries, F. \& Rodríguez, C. (2020). Estilos de aprendizaje y ambiente de aula: situaciones que anteceden a la innovación pedagógica en estudiantes de deporte (Learning style and class environment: situations preceding pedagogical innovation in Sports Science students). Retos, 38(38), 213-221.

Castro, M. B. (2016). A Casa da Xuventude de 0 urense como experiencia histórica de Educación Social. 1978-1992. Pedagogía social: revista interuniversitaria, (27), 16.

Díaz Barahona, J., M onfort Pañego, M ., \& M olinaGarcía, J. (2020). El conocimiento y la intencionalidad didáctica en el uso deTIC del profesorado de educa ción física. Retos: nuevas tendencias en educación física, deporte y recreación, (38), 497-504.

Díaz, P., \& M andado, A. (2004). Deporte y educación: pautas para hacer compatible el rendimiento y el desarrollo integral de los jóvenes deportistas. Revista de educación, 335, 35-44.

ESL M aster España (2020). Recuperado 18 de noviembre de2020, dehttps: / / pro.eslgaming. com/ espana/ bs/

Fradejas Medrano, E., \& Espada Mateos, M. (2017). Evaluación delamotivación en adolescentesque practican deporte en edad escolar (Evaluation of motivation in teenagerswho practice sportsin school age). Retos, (33), 27-33.

Funk, D. C., Pizzo, A. D. \& \& Baker, B. J. (2018). esport management: Embracing esport education and research opportunities. Sport Management Review, 21(1), 7-13.

Fuster Guillen, Doris Elida. (2019). Investigación cualitativa: Método fenomenológico hermenéutico. Propósitosy Representaciones, 7(1), 201229. 
García-Lanzo, S., \& Chamarro, A. (2018). Basic psychological needs, passion and motivations in ama teur and semi-professional esports players. Aloma: revista de psicologia, ciències de l'educació i de l'esport Blanquerna, 36(2), 59-68.

Google Play Store (2020). Recuperado 18 de noviembre de 2020, de https:/ / play.google.com/ store/ apps/ details?id=com. supercell. brawlstars\&gl=ES

Hallmann, K., \& Giel, T. (2018). eSports-Competitive sports or recreational activity? Sport management review, 21(1), 14-20.

Hamari, J. and Sjöblom, M. (2017), «W hat is eSports and why do people watch it?», Internet Research, Vol. 27 No. 2, pp. 211-232.Jackson, B. (2011). Streaming: an education system in miniature (Vol. 180). Routledge.

Juvera Portilla, J. L., Zamarripa, J., Ceballos Gurrola, 0., \& VergaraTorres, A. P. (2020). Pokémon GO y su relación con la actividad física, orientación espa cial y socialización en usuarios mexicanos. Retos: nuevas tendencias en educación física, deporte y recreación, (38), 727-732.

Light, R. L., \& Harvey, S. (2017). Positive pedagogy for sport coaching Sport, Education and Society, 22(2), 271-287.

López M uñiz, G., Jaenes Sánchez, J., Vázquez C ano, E., \& López M eneses, E. (2019). Formación permanente y necesidades de formación de los entrenadores de rugby en andalucía. Retos, 36(36), 115-120.

Méndez-Giménez, A., Fernández-Río, J., \& MéndezAlonso, D. (2015). Modelo de educación deportiva versus modelo tradicional: efectos en la motivación y deportividad. Revista Internacional deM edicina y Ciencias de la Actividad Física y del Deportel International Journal of Medicine and Science of Physical Activity and Sport, 15(59), 449-466.

Ministerio de Cultura y Deporte (2020). Recuperado 18 de noviembre de 2020, de http:// www. culturaydeporte. gob. es/ servicios-al-ciudada no/ estadisticas/ deportes/ anuario-de-estadisticasdeportivas. html.

0 'Connor, E. L., Longman, H., W hite, K. M., \& O bst, P. L. (2015). Sense of community, social identity and social support among players of massively multiplayer online games (MMOGs): a qualitative analysis. Journal of Community \& Applied Social Psychology, 25(6), 459-473.

Parejo, S. G., \& Sánchez, E. G. (2007). Los recursos humanos aplicados a la gestión deportiva (Vol. 658). Inde. Rodríguez Rodríguez, L., \& Miraflores Gómez, E. (2018). Propuesta de igualdad de género en Educa ción Física: adaptaciones de las normas en fútbol. Retos: nuevas tendencias en educación física, de porte y recreación, (33), 293-297.

Santamaría Guzmán, K., Solano M ora, L. C., M oncada Jiménez, J., \& Salicetti Fonseca, A. (2018). M ejora del equilibrio, atención y concentración después de un programa de entrenamiento exergame en la persona adulta mayor. Retos: nuevas tendencias en educación física, deporte y recreación, (33), 102-105.

Statista (2019). Recuperado 18 de noviembre de 2020, dehttps:/ / es.statista.com/ estadisticas/472523/ pla taformas-dejuego-mas-usadas-en-espanar por-numero-de-usuarios/ .

Statista (2020). Recuperado 18 de noviembre de 2020, de https: / / www. statista.com/ statistics/ 1109956/ global-esports-audiencel

Twitch (2020). Recuperado 18 de noviembre de 2020, de https: / / www.twitch.tv/ directory/ game/ Braw|\%20Stars

Twitch tracker (2020). Recuperado 18 de noviembre de 2020, de https:/ / twitchtracker.com/ statistics Varela Crespo, L., Varela Garrote, L., \& FraguelaVale, R. (2020). Perfiles de ocio deportivo en jóvenes españoles (15-20 años): un análisis de género. Retos: nuevas tendencias en educación física, deporte y recreación, (37), 419-426.
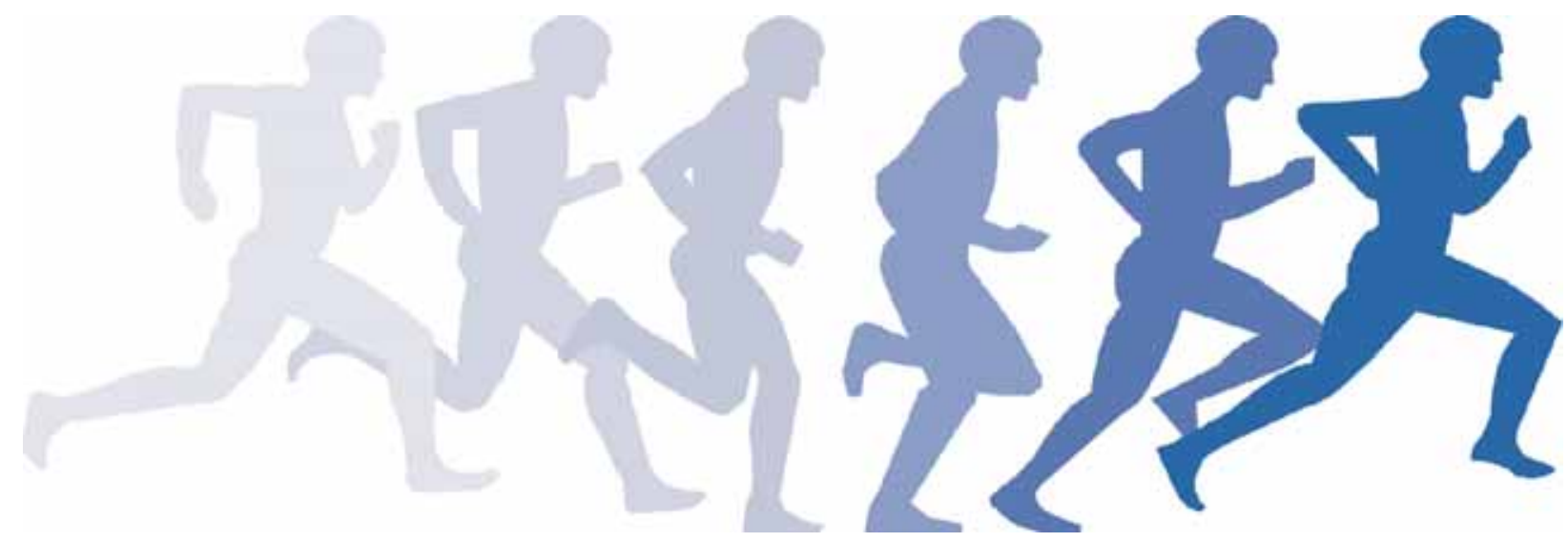